Jurnal Ilmiah METADATA

\title{
TINJAUAN KEKUATAN PEMBUKTIAN DIGITAL SIGNATURE DALAM SENGKETA PERDATA DITINJAU DARI UU NO. 11 TAHUN 2008 TENTANG INFORMASI DAN TRANSAKSI ELEKTRONIK
}

\author{
Novi Juli Rosani Zulkarnaen \\ Universitas Darma Agung, Medan
}

\begin{abstract}
ABSTRAK
Disebabkan perkembangan dunia telematika khususnya internet semakin pesat yang menyebabkan terjadinya transaksi elektronik, maka untuk mencegah terjadinya halhal yang dapat menimbulkan kerugian bagi para pihak yang terikat dalam suatu transaksi, diperlukan suatu pembuktian ataupuan keabsahan dari suatu tanda tangan.
\end{abstract}

Dalam pembahasan penelitian ini penulis mengangkat permasalahan tentang Bagaimana kekuatan hukum penggunaan tanda tangan elektronik dalam transaksi ecommerce menurut Hukum Perdata, serta bagaimana upaya hukum jika terjadi wanprestasi dalam transaksi E-Commerce.

Dalam penulisan penelitian ini penulis menggunakan metode telaah pustaka (library research) untuk mentelaah data-data sekunder dan juga melakukan penelusuran melalui situs internet

Berdasarkan permasalahan yang dikemukakan, maka ditarik kesimpulan bahwa Dengan adanya sertifikat digital yang terdapat dalam transaksi elektronik yang pada umumnya memuat tanda tangan elektronik sudah seharusnya tidak perlu dibuktikan seabsahannya lagi didalam pengadilan karena menurut pengamatan penulis bahwa data yang terdapat dalam sertifikat elektronik telah terjamin keamanannya oleh standar keamanan internasional. Tanda tangan elektronik sesuai dengan fungsi hakiki yang dimiliki olah tanda tangan konvensional pada hakekatnya memiliki kesamaan keberadaan hukum dengan tanda tangan konvensional pada kertas sehingga tanda tangan elektronik telah diakui keabsahannya dalam dunia perdaganan internasional. Upaya hukum yang dilakukan jika terjadi wanprestasi salah satu pihak dalam penggunaan tanda tangan elektronik dalam transaksi melalui E-Commerce, maka pihak yang dirugikan dapat meminta pertanggung jawaban dari pihak yang menimbulkan kerugian untuk memberi ganti rugi kepada pihak yang telah dirugikan..

Kata Kunci : Digital Signature Dalam Sengketa Perdata, UU NO. 11 Tahun 2008 Tentang Informasi Dan Transaksi Elektronik 


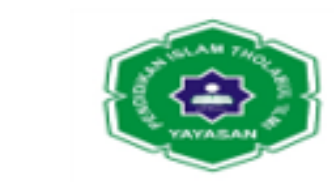

Jurnal Ilmiah METADATA

\section{PENDAHULUAN}

Perkembangan teknologi telekomunikasi elektronik telah melahirkan sebuah peradaban baru yang mengembangkan perdagangan atau transaksi komersial dengan menggunakan media elektronik. Transaksi tersebut dikenal dengan nama $E$ Commerce.

Dalam transaksi E-Commerce memperlihatkan bahwa basis internet dipergunakan sebagai sarana untuk menghubungkan antara penjual dan pembeli. Secara elektronik, transaksi yang dilakukan tetap memperdagangkan barang-barang yang pada umumnya menjadi objek perdagangan biasa, namun terdapat implikasi tertentu karena karakteristik transaksi jenis mencakup hal-hal yang berhubungan dengan adanya informasi, metode pembayaran, yurisdiksi hukum dan kerahasiaan informasi konsumen. Berkaitan dengan ketersediaan informasi, erat kaitannya dengan informasi yang tersedia secara terus menerus dan dapat diakses kapan saja oleh konsumen.

Hal yang menjadi kunci dari hubungan transaksi perdagangan dengan $E$ Commerce adalah menyangkut metode pembayaran. Setiap E-Commerce haruslah memiliki sistem pembayaran elektronik yang mempunyai tingkat perlindungan baik secara yuridis maupun ekonomis. Perselisihan yang timbul dalam E-Commerce pada umumnya dapat bermula dari pada ketidak akuratan dari sistim pembayaran online serta adanya faktor risiko dari penggunaan kartu kredit yang tidak menjamin keamanan dari konsumen. Sebab itu keberhasilan jaringan transaksi E-Commerce juga ditentukan bagaimana setiap transaksi yang terjadi didukung oleh sistem perbankan elektronik yang mencapai jangkauan dunia. Karena diketahui bahwa transaksi tersebut tidak hanya menghubungkan kepentingan penjual atau pembeli dalam satu wilayah tertentu tetapi berlangsung dari satu jaringan elektronik dunia yang berasal dari yurisdiksi hukum yang berbeda pula.

Yurisdiksi hukum dari E-Commerce merupakan salah satu persoalan yang sangat penting karena diperlukan adanya kepastian hukum agar dalam proses 


\section{Jurnal Ilmiah METADATA}

penyelesaian sengketa para pihak mengetahui pilihan hukum mana (choice of law) yang akan ditentukan. Sampai dengan saat ini aspek hukum yang mengatur tentang yurisdiksi E-Commerce masih dalam tahap pengembangan. Belum terdapat perjanjian internasional yang dibuat dalam langkah untuk membangun legal framework yang bersifat multilateral.

Seperti diketahui bahwa E-Commerce menghubungkan dua pihak dalam satu yurisdiksi atau dua pihak dengan yurisdiksi yang berbeda dan sejumlah pihak dengan berbagai yurisdiksi hukum. Dalam kerangka untuk memahami sejauhmana proses hukum berkembang dalam menentukan yurisdiksi hukum maka setiap pengguna $E$ Commerce harus dapat mengerti bahwa saat telah dimulai online transaction di cyberspace maka telah berlaku hukum-hukum tertentu yang disepakati termasuk berbagai risiko yang mungkin timbul dalam rangka penyelesaian transaksi tersebut.

Lintas batas informasi antara penjual dan pembeli menimbulkan topik persoalan yang berhubungan dengan kerahasiaan informasi yang diberikan oleh pembeli pada saat ia menyatakan setuju untuk menyerahkan data elektronik finansial, yaitu kartu kredit kepada penjual. Aspek hukum tentang kerahasiaan informasi ini harus dapat dijamin oleh sistem dan teknologi situs penjual dan tidak semua pihak dapat mengakses data-data yang sedang berlangsung. Dalam aspek ini perkembangan tentang kerahasiaan data akan menentukan sejauhmana tingkat kepercayaan konsumen dalam memanfaatkan jaringan E-Commerce untuk kepentingan transaksi mereka. Tingkat kepercayaan tersebut akan menentukan rasa aman yang diberikan oleh situs-situs finansial. Dalam kerangka kerahasiaan elektronik ini pula maka diperlukan hukum yang memberikan perlindungan kepada konsumen.

Kesulitan-kesulitan yang timbul jika terjadi sengketa antara para pihak di dalam transaksi E-Commerce, bukan saja menyangkut masalah pilihan hukum yang akan diterapkan untuk dijadikan dasar penyelesaian sengketa yang timbul, melainkan juga mengenai pengadilan mana yang mereka pilih untuk menyelesaikan sengketa 
yang mungkin timbul berkenaan dengan pelaksanaan dan penafsiran perjanjian diantara mereka.

Para pihak dapat pula menentukan di dalam perjanjian mereka bahwa sengketa yang timbul akan diselesaikan olehsuatu badan arbitrase baik badan arbitrase intitusional maupun arbitrase ad hoc. Klausul dalam perjanjian yang mengatur mengenai hal ini disebut arbitration provisions atau klausul arbitrase. Perangkat hukum yang bersifat arbitrase dapat merupakan solusi terbaik mengingat besarnya unsur komersial yang terdapat di dalam E-Commerce tersebut. Dari hal tersebut di atas, maka terlihat pentingnya mengetahuu aspek hukum E-Commerce dan perkembangannya di Indonesia sejalan dengan peraturan yang mengatur hal tersebut belum ada yang khusus di Indonesia.

\section{METODE PENELITIAN}

Penelitian ini tergolong sebagai penelitian hukum normatif. Data penelitian ini bersumber dari data sekunder yang bersumber dari bahan-bahan hukum, yang terdiri dari bahan hukum primer, sekunder dan tersier. Penelitian ini menggunakan pendekatan undang-undang dan pendekatan konseptual. Analisis data dalam penelitian ini menggunakan analisis data kualitatif.

\section{HASIL DAN PEMBAHASAN}

\section{A. Tinjauan Tentang Kontrak Dagang Elektronik}

Secara terminologi, kata kontrak berasal dari bahasa Inggris "contract” yang berarti perjanjian atau kontrak, ${ }^{5}$ namun secara tertulis ada istilah lain yang juga sering dipergunakan seperti “agreement" yang berarti persetujuan, permufakatan dan ada juga yang mengartikan kata agreement tersebut dengan perjanjian. Dalam praktek

\footnotetext{
${ }^{5}$ Marriam Darus Badrulzaman, Op. Cit, h. 280
} 


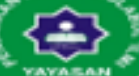

\section{Jurnal IImiah METADATA}

penyusunan kontrak kedua istilah tersebut tidak dipermasalahkan, tergantung praktek para pihak yang menggunakan istilah mana yang lebih disukai.

Dalam Kibat Undang-undang Hukum Perdata, selain istilah kontrak juga digunakan istilah persetujuan yang pada dasarnya pengertian istilah tersebut sama dengan pengertian perjanjian, hal ini dapat kita ketahui dalam Buku III Bab Kedua tentang "Perikatan-perikatan yang dilahirkan dari Kontrak atau Persetujuan". Menurut ketentuan Pasal 1313 KUH Perdata, "perjanjian/persetujuan adalah suatu perbuatan dengan mana seorang atau lebih mengikatkan dirinya terhadap satu orang lain atau lebih". Pengertian perjanjian menurut Pasal 1313 KUH Perdata tersebut sangat luas dan mendalam, hal ini menyebabkan timbul berbagai pengertian tentang kontrak, namun pada dasarnya dan tujuan penyampaian pengertian adalah sama, misalnya R. Subekti, mengartikan perjanjian adalah suatu peristiwa dimana ada seorang berjanji kepada seorang lain atau dua orang itu saling berjanji untuk melaksanakan sesuatu hal, dari peristiwa itu, timbullah suatu hubungan antara dua orang tersebut yang dinamakan "perikatan". Oleh karena itu, perjanjian menerbitkan suatu perikatan antara dua orang yang membuatnya. "Pendapat lain mengemukakan Perikatan adalah hubungan hukum yang terjadi diantara dua orang atau lebih, yang terletak di dalam lapangan kekayaan dimana pihak yang satu berhak atas prestasi dan pihak lainnya wajib memenuhi prestasi"'6. Dari rumusan tersebut terlihat bahwa perikatan terdiri dari empat unsur, yaitu :

a. Hubungan hukum

b. Kekayaan

c. Pihak-pihak

d. Prestasi

Hubungan yang terjadi antara para pihak di atur oleh hukum melakukan hak pada satu dan meletakkan kewajiban pada pihak lain, apabila salah satu pihak hukum akan memaksa supaya hukum tersebut dipenuhi.

${ }^{6}$ Ibid, h. 3 


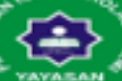

Jurnal Ilmiah METADATA

Dengan demikian kontrak Dagang Elektronik, yaitu kontrak dagang yang mempergunakan elektronik dan mempunyai tempat di dunia maya.

Ada dua macam bentuk kontrak atau perjanjian yang dikenal, yaitu tertulis dan tidak tertulis atau lisan. Dalam praktek khususnya kontrak dagang selalu terbuat secara tertulis, karena perjanjian tertulis dapat dijadikan alat bukti tertulis terjadinya perjanjian para pihak, disamping penting untuk menghindari adanya ketidakpastian akan kesepakatamn yang telah mengikat diantara para pihak. Perjanjian atau kontrak tertulis merupakan surat yang berupa akta, sedangkan akta terdiri dari dua macam yaitu akta otentik dan akta dibawah tangan. "Akta otentik adalah akta yang dibuat oleh pejabat yang diberi wewenang untuk itu oleh penguasa, menurut ketentuanketentuan yang telah ditetapkan, baik dengan maupun dengan bantuan dari yang berkepentingan, yang mencatat apa yang dimintakan untuk dimuat didalamnya oleh yang berkepentingan". 7 Defenisi ini sama dengan pengertian akta otentik yang ditentukan dalam Pasal 1868 KUH Perdata, yang intinya akta otentik tersebut :

a. Akta yang dibuat oleh pejabat umum.

b. Dalam bentuk yang ditentukan UU.

c. Ditempat mana pajabat itu berwenang membuatnya.

Bentuk kontrak dagang elektronik yang selama ini berkembang mencakup suatu kontrak yang dibentuk secara sah melalui komunikasi e-mail. Penawaran dan penerimaan dapat dipertukarkan e-mail atau dikombinasi dengan komunikasi elektronika lainnya, dokumen tertulis, faks dan lain-lain.

Suatu kontrak dapat juga dibentuk melalui web site dan jasa online lain, yaitu suatu web site menawarkan penjualan barang dan jasa dan konsumen dapat menerima penawaran dengan mengisi dan mentransmisi suatu formulir yang tertampung pada layar monitor.

\footnotetext{
${ }^{7}$ Joni Emirzon, op.Cit, h. 20
} 


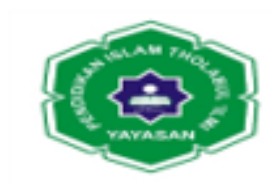

\section{Jurnal Ilmiah METADATA}

"Bentuk kontrak lain adalah yang mencakup direct on-line trasnfer dari informasi dan jasa, website digunakan sebagai medium of communication dan sekaligus sebagai medium of exchange". ${ }^{8}$

Kontrak yang berisi "Electronic Data Interchange (EDI), adalah suatu pertukaran informasi bisnis secara elektronik dalam Computer Processable Format melalui komputer milik para mitra dagang (trading patners)". ${ }^{9}$

Suatu cara berkontrak dalam internet dapat bersifat perjanjian lisensi Click-Wrap dan Shrink-Wrap : Soft ware yang di download dari internet lazimnya dijual dengan suatu lisensi click-wrap. Lisensi tersebut muncul pada monitor pembeli pada saat pertama kali software akan dipasang (install) dan calon pembeli ditanya apakah ia bersedia menerima persyaratan tersebut sebelum menggunakan program tersebut. Pengguna dapat meng-klik "I accept"atau "I don't accept" apabila pembeli menyetujui persyaratan lisensi, software tersebut dapat dipasang (install). ${ }^{10}$

Pihak-pihak di dalam kontrak dagang elektronik adalah sebagai berikut :

a. Penyediaan jasa internet (Internet Service Provider : ISP)

ISP adalah pemilik ruang elektronik disebut website/keybase yang terdiri dari site yang satu yang lainnya dapat dibedakan. Untuk mengembangkan saluran elektronik ini, ISP dipasarkan kepada masyarakat untuk akses internet. Dengan mempergunakan usaha pengembang/penyalur jasa internet.

Pengembang disebut intellegent agent dari ISP. Agen ini membantu ISP untuk mengembangkan konsep ISP yang mempermudah tugas-tugasnya. Misalnya akses terhadap infrastruktur yang diperlukan antara lain pemeliharaan perangkat lunak (maintenance), mengudarakan site serta infrastruktur teknis lainnya.

b. Pengembang (intelectual agent) adalah pelaku bisnis yang mengadakan kontrak dagang langsung dengan ISP.

\footnotetext{
${ }^{8}$ Mieke Komar Kanta atmadja, Cyberlaw Suatu Pengantar, Penerbit, ELIPS, Bandung, 2002

${ }^{9}$ Ibid, h. 36

${ }^{10}$ Ibid, h.37
} 


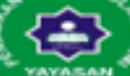

\section{Jurnal IImiah METADATA}

ISP dan agen harus online selama 24 jam setiap hari selama 7 (tujuh) hari per minggu agar dapat dikunjungi para calon konsumen/pemakai (customer). Disamping itu, ditentukan prosedur untuk mengaktifkan online situs tersebut. ISP dan agen pada tanggal tertentu harus mengudara bersama situsnya untuk memenuhi janji-janji terhadap para inventor.

\section{B. Tinjauan Tentang E-Commerce}

Dalam beberapa waktu terakhir ini, media internet telah berkembang dimanamana. Khusus di Indonesia internet telah membuat banyak perusahaan mulai mencoba menawarkan berbagai macam produk mereka dengan menggunakan media ini. Kehadiran internet yang walaupun masih merupakan industri baru yang dalam tahap pertumbuhan, yang masih terus berubah serta penuh ketidakpastian, telah memperkokoh keyakinan akan pentingnya peranan teknologi dalam pencapaian tujuan finansial perusahaan melalui modifikasi dan efisiensi proses binsis, yaitu dengan memanfaatkan E-Commerce.

E-Commerce merupakan salah satu keunggulan dari internet, hingga akirnya di era sekarang ini nampaknya tiada hari yang terlewatkan tanpa mendengar atau membaca kata E-Commerce di berbagai media informasi.

Sebenarnya dalam E-Commerce banyak sebutan yang dipakai untuk memudahkan orang mengucapkannya. Ada beberapa sebutan untuk E-Commerce yaitu internet commerce atau ecom, atau E-Commerce, ataua immerce, yang pada dasarnya semua sebutan di atas mempunyai makan yang sama. Istilah-istilah tersebut berarti, membeli atau menjual barang secara elektronik, dan kegiatan ini dilakukan pada jaringan internet." E-Commerce juga dapat berarti pemasangan iklan, penjualan dan dukungan dan pelayanan yang terbaik menggunakan sebuah web shop 24 jam sehari bagi seluruh pelanggarannya". ${ }^{11}$

Jullian Ding memberikan defenisi tentang E-Commerce sebagai berikut :

\footnotetext{
${ }^{11}$ Wahana Komputer, Loc.Cit
} 


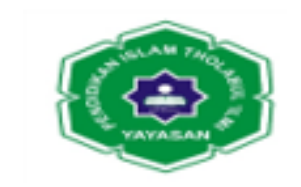

\section{Jurnal Ilmiah METADATA}

Dalam terjemahan adalah sebagai berikut : Electronic Commerce Transaction adalah transaksi dagang antara penjual dengan pembeli untuk menyediakan barang, jasa, atau mengambil alih hak. Kontrak ini dilakukan dengan media elektronik (digital medium) di mana para pihak tidak hadir secara fisik. Medium ini terdapat di dalam jaringan umum dengan sistem terbuka yaitu internet atau World Wide Web. Transaksi ini terjadi terlepas dari batas wilayah dari batas wilayah dan syarat nasional. ${ }^{12}$

Defenisi E-Commerce sendiri sangat beragam, bergantung pada perspektif atau kacamata yang memanfaatkannya. Association For E-Commerce secara sederhana mendefenisikan E-Commerce sebagai "mekanisme bisnis secara elektronik". Commerce Net, sebuah konsorsium industri memberikan defenisi yang lebih lengkap yaitu "Penggunaan jaringan komputer sebagai sarana penciptaan relasi bisnis". Tidak puas dengan defenisi tersebut, Commerce Net menambahkan bahwa dalam E-Commerce terjadi "proses pembelian dan penjualan jasas atau produk antara kedua belah pihak melalui internet atau pertukaran dan distribusi informasi antar dua belah pihak di dalam satu perusahaan dengan menggunakan internet”. Beberapa kalangan akademispun sepakat mendefenisikan E-Commerce sebagai "salah satu cara memperbaiki kinerja dan mekanisme pertukaran barang, jasa, informasi, dan pengeluaran dengan memanfaatkan teknologi berbasis jaringan peralatan digital". ${ }^{13}$

Chissick dan Kelman memberikan defenisi yang sangat global terhadap E-Commerce sebagai " a broad described business activities with associated technical data that are conducted ellectronically, Atau istilah yang luas menggambarkan aktivitas-aktivitas dengan data teknis yang terasosiasi yang dilakukan secara atau dengan menggunakan media elektronik". ${ }^{14}$

Dalam rancangan Undang-undang Kegiatan dan Penggunaan Teknologi Informasi dikatakan bahwa perdagangan secara elektronik ialah setiap perdagangan baik

12 Marriam Darus Badrulzaman, Loc.Cit

13 Richardus Eko Indrajit, E-Commerce Kiat dan Strategi Bisnis di Dunia Maya, Penerbit PT. Elex Media Komputindo, Gramedia, Jakarta, 2001, h. 1-2

${ }^{14}$ M. Arsyad Sanusi, E-Commerce Hukum dan Solusinya, PT. Mizan Grafika, 2001, hl 14 


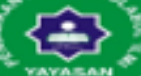

\section{Jurnal Ilmiah METADATA}

barang maupun jasa yang dilakukan melalui jaringan komputer atau media elektronik lainnya.

Dalam sumber kutipan yang sama Kamlesh K. Bajaj dan Debjani Nag mengatakan, "E-Commerce merupakan suatu bentuk pertukaran informasi bisnis tanpa menggunakan kertas (paperless exchange of business information) melainkan dengan menggunakan EDI (Electronic Data Interchange), Electronic Mail (E-Mail), Electronic Bulletin Boards (EBB), Electronic Funds Transfer (EFT) dan melalui jaringan elektronik lainnya". ${ }^{15}$

Upaya-upaya yang telah dilakukan pemerintah dalam hal pembentukan hukum cyber adalah sebagai berikut :

a. Undang-undang Telekomunikasi Nomor 36 Tahun 1999

Dalam Pasal 1 ayat (1) Undang-undang Telekomunikasi Nomor 36 Tahun 1999 dikatakan bahwa "Telekomunikasi adalah setiap pemancar, pengiriman, dan atau penerimaan dari setiap informasi dalam setiap tanda-tanda, tulisan, gambar, dan bunyi melalui sistem kawat, optik, radio atau sistem elektro magnetik lainnya". Dengan demikian, komunikasi yang mempergunakan media elektronik seperti internet tercakup di dalam Undang-undang ini.

b. Naskah RUU tentang Teknologi Informasi Tahun 2000

Naskah Akademik ini adalah hasil kerjasama antara Pusat Studi Cyberlaw Fakultas Hukum Universitas Padjajaran dan LAPI Institut Teknologi Bandung. Salah satu tujuan dari pengkajian ini adalah untuk menentukan model dan materi Rancangan Undang-undang tentang Teknologi informasi yang sesuai dengan sistem hukum Indonesia yang akan digunakan sebagai payung untuk kegiatan teknologi informasi.

c. Naskah Akademik Rancangan Undang-undang tentang Tanda Tangan Elektronik dan Transaksi Elektronik

${ }^{15}$ Ibid, h. 15 


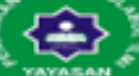

\section{Jurnal IImiah METADATA}

Adalah hasil kerjasama antara Dirjen Perdagangan Dalam Negeri dan Deperindag Jakarta dengan Lembaga Kajian Hukum Teknologi Fakultas Hukum Universitas Indonesia. Mengacu pada sistem pembentukan hukum yang kita anut adalah parsial, maka pembentukan hukum tersebut dapat diadakan bagian demi bagian dengan prioritas, misalnya tanda tangan elektronik, sistem pengamanan, penyelesaian sengketa, dan lain-lain. Tentang elemen-elemen dari hukum kontrak, maka KUH Perdata tentang ajaran umum hukum perjanjian dapat dipergunakan secara analogi. Sementara itu, dapat juga dipergunakan alternatif lain, yaitu mensyahkan penggunaan Model Law tentang E-Commerce yang dibentuk UNCITRAL. Sejalan dengan perkembangan itu, berkembang pula sengketa tentang kontrak dagang elektronik itu, antara lain ingkar janji melakukan pembayaran. Kita dapat membayangkan kesulitan dalam menegakkan hukum akibat kontrak dagang elektronik dan karena penganutnya sangat mendesak. Untuk menyelesaikan sengekta ini, para pakar berupaya menciptakan lembaga arbitrase elektronik.

\section{Kedudukan Kontrak Elektronik E-Commerce Dalam Hukum Perdata}

Pasal 1313 KUH Perdata menyatakan bahwa perjanjian adalah suatu perbuatan dengan mana satu orang atau lebih mengingatkan dirinya terhadap satu orang lain atau lebih. Pengertian perjanjian yang diberikan oleh ketentuan ini ternyata mempunyai kelemahan. Menurut Abdul Kadir Muhammad, kelemahan-kelemahan itu antara lain meliputi :

1. Hanya menyangkut sepihak saja. Hal ini diketahui dari perumusan "satu orang atau lebih mengikatkan dirinya terhadap satu orang atau lebih". Kata kerja mengikatkan dirinya hanya datang dari satu pihak saja, tidak dari kedua belah pihak. Seharusnya perumusan itu "saling mengikatkan diri". Jadi ada konsensus antara pihak-pihak.

2. Kata perbuatan mencakup juga tanpa konsesus. Dalam pengertian "perbuatan" termasuk juga tindakan melaksanakn tugas tanpa kuasa 


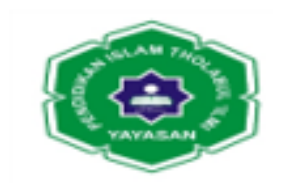

\section{Jurnal Ilmiah METADATA}

(zaakwaarneming), tindakan melawan hukum (onrechtmatige daad) yang tidak mengandung satu konsensus. Seharusnya dipakai kata "persetujuan".

3. Pengertian perjanjian terlalu luas. Pengertian perjanjian dalam pasal tersebut di atas terlalu luas, karena mencakup juga pelangsungan perkawinan, janji kawin, yang diatur dalam lapangan hukum keluarga. Padahal yang dimaksud adalah lapangan hukum antara debitur dan kreditur dalam lapangan harus kekayaan saja. Perjanjian yang dikehendaki oleh buku ketiga KUH Perdata sebenarnya hanyalah perjanjian yang bersifat kebendaan, bukan perjanjian yang bersifat personal.

4. Tanpa menyebut tujuan. Dalam perumusan pasal itu tidak disebutkan tujuan mengadakan perjanjian sehingga pihak-pihak yang mengikatkan diri itu tidak jelas untuk apa. Dengan kelemahan-kelemahan ini dapat dikemukakan beberapa pendapat para ahli mengenai pengertian dari perjanjian. ${ }^{39}$

Setelah melihat kepada pengertian perjanjian yang diberikan oleh para ahli hukum, maka aspek terpenting dari suatu perjanjian adalah perlunya pemenuhan syarat-syarat perjanjian itu sendiri. Pasal 1320 menentukan syarat-syarat perjanjian, yaitu :

1. Kata sepakat atau sepakat mereka yang mengikatkan dirinya.

Hal ini dimaksudkan, bahwa para pihak yang hendak mengadakan perjanjian, harus terlebih dahulu bersepekat atau setuju mengenai hal-hal yang pokok dari perjanjian yang akan diadakan itu. Kata sepakat tidak sah apabila kata sepakat itu diberikan karena kekhilafan, paksaan, ataupun penipuan (Pasal 1321 KUH Perdata).

2. Cakap bertindak atau kecakapan untuk membuat perjanjian.

Pada dasarnya, setiap orang adalah cakap untuk membuat perjanjian, kecuali jika oleh Undang-undang tidak dinyatakan tak cakap (Pasal 1329) KUH Perdata. Menurut Pasal 1330 KUH Perdata, mereka yang tidak cakap membuat suatu perjanjian adalah :

1. Orang yang belum dewasa.

2. Mereka yang dibawah pengampunan.

${ }^{39}$ Abdul Kadir Muhammd, Hukum Perikatan, PT. Aditya Bakti, Bandung, 1992, h. 44 


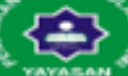

\section{Jurnal IImiah METADATA}

3. Orang perempuan dalam hal-hal yang ditetapkan Undang-undng

4. Semua orang kepada siapa Undang-undang telah melarang membuat perjanjian tertentu.

3. Ada objek atau adanya suatu hal tertentu.

Objek perjanjian harus jelas ditentukan. Menurut Pasal 1333 KUH Perdata, suatu perjanjian harus mempunyai pokok sebagai suatu barang yang paling sedikit jenisnya.

4. Kausa halal atau adanya suatu sebab yang halal

Isi perjanjian tidak bertentangan dengan ketertiban umum, kesusilaan, dan Undang-undang (Pasal 1337 KUH Perdata).

Apabila perjanjian itu sudah memenuhi keempat persyaratan itu, maka perjanjian tersebut sah hukumnya. Akan tetapi, apabila perjanjian itu tidak memenuhi syarat pada point 1 dan 2, maka perjanjian batal demi hukum dan apabila perjanjian itu tidak memenuhi ponit 3 dan 4, maka perjanjian itu dapat dibatalkan.

Perjanjian yang ada pada ketentuan Buku III KUH Perdata memiliki sifat terbuka. Arti dari sifat terbuka bahwa para pihak bebas untuk melakukan perjanjian di antara mereka, meskipun perjanjian itu tidak diatur (asas kebebasan berkontrak), asalkan hal ini pada dasarnya tidak harus dibuat pada bentuk tertentu (tertulis). Perjanjian yang ada kenyataannya dilakukan secara bebas. Perjanjian itu dapat

dikatakan dalam bentuk lisan dan apabila diterapkan dalam suatu tulisan, itu seringkali mempunyai sifat alat pembuktian semata-mata. Meskipun demikian ada beberapa perjanjian yang mensyaratkan harus dibuat dalam bentuk tertulis.

Apabila kajian teoritis perjanjian ini dijadikan pola pendekatan dalam menganalisis apakah kontrak yang dibuat dalam media elektronik sah atau tidak, hal tersebut tentunya dapat saja dilakukan. Seperti diketahui, ketentuan hukum dimaksudkan untuk mempertegas hubungan-hubungan hukum. 


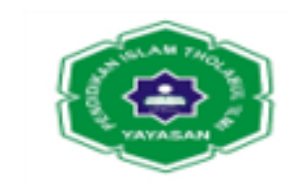

\section{Jurnal Ilmiah METADATA}

"Di Indonesia ada sebuah yurisprudensi yang menyatakan bahwa faksmile dapat dijadikan sebagai alat bukti"40. Hal ini dapat ditentukan pada putusan Mahkamah Agung RI No. 9K/N/1999. Berdasarkan yurisprudensi ini pula maka sebenarnya adalah tidak merupakan suatu masalah apabila perjanjian itu dibuat dalam bit-bit data. File komputer (text, bitmap, sound) yang di encrypt dengan menggunakan digital signature dapat dimanfaatkan guna membentuk suatu perjanjian. File komputer dari digital signature dapat juga dijadikan bahan pembuktian. Cara yang ditempuh dengan membuat perjanjian diantara para pihak berupa perjanjian bukti/perjanjian penetapan.

\section{Bentuk Pembuktian Adanya Transaksi E-Commerce Dan Hubungan Hukum Para Pihak Dalam Transaksi E-Commerce \\ Untuk eksistensi kontrak dagang elektronik diperlukan sejumlah alat bukti. Alat} bukti yang diatur dalam KUH Perdata Buku IV, ditentukan bahwa setiap orang yang mendalilkan atau guna meneguhkan haknya sendiri maupun membantah hak orang lain menunjuk pada suatu peristiwa, atau peristiwa tersebut (Pasal 1865 KUH Perdata). Alat-alat bukti terdiri atas :

1. Bukti Tulisan

Pembuktian dengan tulisan dilakukan dengan tulisan yang otentik maupun dengan tulisan tangan. Suatu akta otentik adalah suatu akta yang di dalam bentuk diten tukan Undangundang dibuat oleh atau dihadapan pegawai umum yang berkuasa itu mana tempat akta itu dibuat.

2 Saksi-saksi

Keterangan seorang saksi saja tanpa alat bukti lain di muka pengadilan tidak boleh dipercaya, semua orang yang cakap untuk menjadi saksi diharuskan menjadi saksi di depan hakim. Tiap-tiap kesaksian harus disertai dengan alasan-alasan bagaimana diketahuinya hal-hal yang diterangkan, pendapat maupun perkiraan khusus bukanlah kesaksian (Pasal 1095, Pasal 1096 dan Pasal 1097 KUH Perdata).

3. Persangkaan

\footnotetext{
${ }^{40}$ Riyeke Ustadiyanto, Op.Cit, h. 123
} 


\section{(-)}

\section{Jurnal Ilmiah METADATA}

Persangkaan adalah kesimpulan yang oleh Undang-undang atau hak im ditariknya dari suatu peristiwa yang terkenal ke arah suatu peristiwa yang tidak terkenal

4. Pengakuan

Pengakuan yang dikemukakan terhadap suatu pihak ada yang dilakukan di muka hakim dan ada yang dilakukan di luar sidang pengadilan. Pengakuan yang dilakukan di muka hakim memberikan suatu bukti yang sempurna terhadap siapa yang telah melakukannya, baik sendiri maupun dengan peraturan seorang yang khusus untuk itu. Suatu pen gakuan yang dilakukan di muka hakim tidak dapat ditarik kembali kecuali apabila dibuktikan bahwa pengakuan itu adalah akibat dari suatu kekhilafan dari suatu hal-hal yang terjadi.

5. Sumpah di Muka Hakim

Ada 2 (dua) macam sumpah di muka hakim :

a. Sumpah yang oleh pihak yang satu diperintahkan kepada pihak yang lain untuk menggantungkan perumusan perkara padanya, sumpah ini dinamakan sumpah pemutus.

b. Sumpah yang oleh hakim karena jabatannya diperintahkan kepada salah satu pihak

Sampai saat ini sistem pembuktian hukum privat masih menggunakan ketentuan yang diatur di dalam BW, HIR (untuk Jawa Madura) dan Rbg (untuk luar Jawa Madura). Dalam hukum pembuktian ini, alat-alat bukti dalam perkara perdata tediri dari : bukti tulisan, bukti saksi-saksi, persangkaan-persangkaan, pengakuan dan bukti sumpah (Pasal 1866 BW atau 164 HIR).

Sementara itu, dengan pesatnya teknologi informasi melalui internet sebaimana telah dikemukakan, yaitu telah mengubah berbagai aspek kehidupan, diantaranya men gub ah kegiatan perdagangan yang semula dilakukan dengan cara kontak fisik, kini dengan in ternet kegitan perdagangan dilakukan secara elektronik (Electronic Commerce atau E-Commerce).

Keadaan tersebut di atas belum mendapat pengaturan dalam sistem hukum pembuktian, karena sampai saat ini hukum pembuktiannya masih menggunakan ketentuan hukum yang lama (BW, HIR dan Rbg). Namun demikian, keberadaan UU No. 8 Tahun 1997 tentang Dokumen Perusahaan (UU No. 8 Tahun 1997) telah mulai melihat ke arah pembuktian data elektronik. 


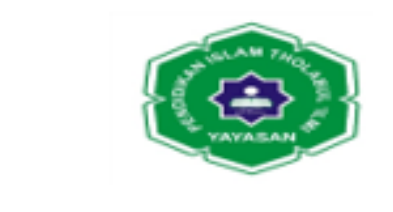

\section{Jurnal Ilmiah METADATA}

Memang UU No. 8 Tahun 1997 tidak mengatur masalah pembuktian, namun UU ini telah memberikan kemungkinan kepada dokumen perusahaan yang telah diberi kedudukan sebagai alat bukti tertulis otentik untuk diamankan melalui penyimpanan dalam mikro film. Selanjutnya, terhadap dokumen yang disimpan dalam bentuk elektronik (paperless) ini dapat dijadikan sebagai alat bukti yang sah. Di samping itu dalam Pasal 3 UU No. 8 Tahun 1997 telah memberi peluang luas terhadap pemahaman atas alat b ukti, yaitu "Dokumen keuangan terdiri dari catatan, bukti pembukuan, dan data pendukung administrasi keuangan, yang merupakan adanya bukti hak dan kewajiban serta kegiatan usaha perusahaan". Selanjutnya Pasal 4 UU tersebut menyatakan : "Dokumen lainnya ter diri dari data atau setiap tulisannya yang berisi keterangan yang mempunyai nilai guna bagi perusahaan meskipun tidak terkait langsung dengan dokumen perusahaan”.

Berdasarkan uraian tersebut, maka tampaknya UU ini telah memberi kemungkinan dokumen perusahaan untuk dijadikan sebagai alat bukti.

Hukum pembuktian pardata sebagaimana telah dikemukakan telah meny ebutkan alat-alat bukti secara limitatif yaitu hanya menyebutkan 5 macam alat bukti. Dari kelima macam alat bukti tersebut dalam perkara perdata, bukti tulisan mendapat kedudukan sebagai alat bukti yang utama, apalagi yang disebut dengan bukti tulisan yang berupa akta otentik. Akta otentik memiliki kekuatan pembuktian formil, materil dan mengikat ke luar.

Kiranya bukan hanya peraturan perundang-undangan di Zaman Hindia Belanda saja, bahkan yang dibuat di zaman kemerdekaan sekalipun tidak sedikit yang telah ketinggalan atau setidak-tidaknya tidak sesuai lagi dengan kenyata an masyarakat. Akibat kenyataan tersebut muncul istilah yang menyatakan "het recht hinkt achterde feiten aan". Artinya hukum ketinggalan dengan peristiwa yang diaturnya. Peristiwa atau kepentingan 


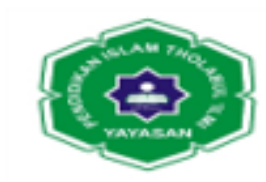

\section{Jurnal Ilmiah METADATA}

manusia sudah berkembang jauh, tetapi hukumnya masih yang itu juga. ${ }^{41}$ Sementara itu, menurut Prof. Mochtar Kusumaatmadja, bahwa hukum harus merupakan sarana pembaharuan masyarakat. Artinya hukum harus berada di depan peristiwa yang terjadi di masyarakat.

Adapun beberapa asas yang penting diindahkan dalam hukum pembuktian, yaitu :

Pertama, asas Audi et alteram partem yaitu bahwa kedua belah pihak yang bersengketa harus diperlakukan sama atau dalam praktek dikenal dengan "equal justice unde low.

Kedua, gugatan harus diajukan pada pengadilan dimana tergugat bertempat tinggal atau dikenal dengan "Actor sequitur forum rei". Asas ini dikembangkan bertolak dari apa yang dikenal dalam hukum pidana dengan "Presumption of innocense".

Ketiga, asas “Actori incumbit probatio”, yaitu bahwa siapa yang mengaku memiliki hak harus membuktikannya, asas ini berdasarkan kepada apa yang tampak telah ada secara sah haruslah untuk sementara dibiarkan dalam keadaan demikian untuk kepastian hukum. Namun demikian, yang harus dibuktikan tersebut hanyalah yang positif saja, yaitu adanya suatu peristiwa dan bukan tidak adanya peristiwa.

Asas-asas tersebut berlaku dalam hukum acara perdata (hukum pembuktian yang umum), sedangkan untuk hukum pembuktian dalam rancangan Undang-und ang Teknologi Informatika, hukum pembuktian yang bersifat khusus (lex spesialis), harus tetap mengacu pada hukum pembuktian yang umum.

${ }^{41}$ Sudikno Mertokusumo, Bunga Rampai Ilmu Hukum,Liberty, Yogyakarta, 1984, h. 17 


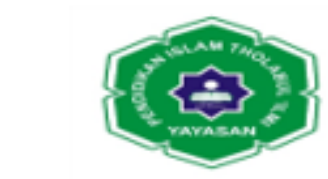

\section{Jurnal Ilmiah METADATA}

Dengan semakin majunya bidang teknologi khususnya teknologi informasi, sehingga perlu diatur tentang pokok-pokok materi hukum pembuktian dalam RUU Teknologi Informatika.

Kemajuan yang pesat di bidang teknologi berdampak pada dunia bisnis, yaitu bisnis dapat dilakukan melalui cyberspace atau dikenal dalam praktek dewasa ini sebagai $E$ Commerce. Faktor ini sangat mendesak untuk segera dibuat pengaturan cyberspace dalam peraturan perundang-undangan.

Hukum pembuktian yang diatur dalam RUU Teknologi Informatika harus bersifat khusus, seperti halnya dalam beracara perdata kepailitan pun demikian. Bidang-bidang hukum lainnya seperti hukum perdata dan sebagainya yang mengatur masalah pembuktian tetap diakui sebagai hukum umum. Artinya Undang-undang yang sudah ada dibiarkan tetap mengatur secara umum sebelum ada pencabutan terhadap ketentuan-ketentuan Undangundang tersebut yang baru sebagai hukum akan patuh pada asas lex spesialis derogat lex generalis.

Dengan demikian, apabila terjadi sengketa mengenai teknologi informatika, hakim mempergunakan cara-cara pembuktian sebagaimana diatur dalam hukum teknologi informatika. Sekarang masalahnya dalam hukum pembuktian RUU Teknologi Informatika diatur dihapuskannya penyebutan alat-alat bukti yang dapat digunakan. Hakim diberi kebebasan untuk menerima semua alat bukti yang diajukan sebagai alat bukti. Namun demikian, ada pembatasan pula bagi hakim untuk mengakui dan menerima isi dari kekuatan pembuktian dari beberapa alat bukti tertentu yang telah ditentukan oleh Undang-undang (dwingend bewijs), seperti akta otentik, akta di bawah tangan dan sebagainya yang sekiranya 


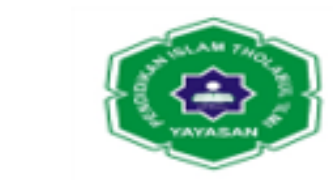

\section{Jurnal Ilmiah METADATA}

sudah merupakan hal yang umum dan diakui secara universal. Terhadap $d$ wingend bewijs in $\mathrm{i}$ harus dimungkinkan pembuktian lawan dengan disertai saksi-saksi.

\section{Digital Signature Sebagai Alat Bukti}

Pembuktian menurut Pitlo adalah suatu cara yang dilakukan oleh suatu pihak atas fakta dan hak yang berhubungan dengan kepentingannya. Subekti berpendapat bah wa yang dimaksud dengan membuktikan adalah meyakinkan hakim tentang kebenaran dalil atau dalil yang dikemukakan dalam suatu persengketaan. Sementara keten tuan Pasal 163 HIR (283 Rbg) menyatakan setiap orang yang mendalilkan bahwa ia mempunyai suatu hak, atau guna meneguhkan haknya sendiri maupun membantah hak orang lain, menunjuk pad suatu peristiwa di wajibkan membuktikan adanya hak atau peristiwa tersebut. Dari sini ada dua aspek yang perlu diperhatikan dalam pembuktian, yakni yang menyangkut dalil peristiwa dan adanya hak.

Proses pembuktian baru terjadi apabila ada di antara para pihak. Sengketa itu sendiri biasanya penyelesaiannya ditentukan oleh salah satu klausula dalam kontrak. Umumnya penyelesaian itu dapat melalui lembaga litigasi atau non litigasi. Khusus untuk pembahsan, pembuktian ini diarahkan pada pola penyelesaian di lembaga peradilan.

Dalam konteks hukum Indonesia, pembuktian mengacu pada hukum acara perdata." Dasar beracara dalam perkara perdata pengaturannya ditentukan dalam HIR (Herzien Inlands Reglements) atau RIB (Reglemen Indonesia yang diperbaharuan) ", ${ }^{42}$

Dalam Pasal 164 HIR (283 RBg) dan 1093 BW ada lima alat bukti yang dapat diajukan dalam proses persidangan. Alat bukti itu adalah :

a. Bukti tulisan

\footnotetext{
${ }^{42}$ Riyeke Ustadiyanto, op.cit h. 124
} 


\section{(-)}

\section{Jurnal Ilmiah METADATA}

b. Bukti dengan saksi

c. Persangkaan-persangkaan

d. Pengakuan

e. Sumpah

Apabila melihat pada ketentuan ini, digital siganture tidak dimungkinkan untuk digunakan sebagai alat bukti atau akan ditolak baik oleh hakim maupun pihak lawan karen a pembuktian yang dikehendaki berdasarkan pada ketentuan di atas mensyaratkan bahwa alat bukti itu berupa tulisan, sementara digital signature sifatnya tanpa kertas.

Akan tetapi ketidakmungkinan digital siganture dipakai sebagai alat bukti tidaklah absolut, namun relatif sifatnya. Sebab menurut Hukum Acara Perdata Indonesia, apabila ada sengketa kemungkinan sengketa itu diserahkan pada hakim dalam penyelesiannya, maka hakim tidak boleh menolak perkara tersebut dengan alasan tidak ada hukumnya (asas ius curia novit). Artinya jika terjadi sengketa dalam transaksi pembayaran elektronis antara para pihak, maka hakim pun wajib untuk menerimanya.

Dengan alasan ini pula sebenarnya hakim di Indonesia diberi keleluasaan untuk menemukan hukum. Seandainya terjadi sengketa dalam transaksi pembayaran, maka sebenarnya dengan metode penemuan hukum hakim dapat saja menganggap bahwa digital signature sebagai alat bukti. Dengan catatan hakim harus dibekali pengetahuan yang cukup mengenai skema sistem pembayaran elektronik atau setidaknya mengetahui mekanisme sistem pembayaran elektronik yang secara interprestasi analogis dan interplementasi ekstensif.

Interprestasi analogis merupakan penemuan hukum yang dilakukan oleh hakim dengan cara memberi penafsiran pada suatu peraturan hukum dengan memberi kias pada 


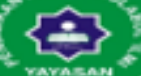

\section{Jurnal Ilmiah METADATA}

kata-kata dalam peraturan tersebut sesuai dengan asas hukumnya, sehingga suatu peristiwa yang sebenarnya tidak dapat dimasukkan kemudian dianggap sesuai dengan bunyi peraturan tersebut. contohnya analogi mengenai aliran listrik dan data elektronik. Dalam kaitan ini digital siganature sebagai data elektronik belum ada peraturannya secara khusus, maka dalam proses pembuktian dapat dilakukan melalui metode interprestasi analogis.

\section{KESIMPULAN}

Kontrak Dagang Elektronik adalah suatu fenomena yang baru, oleh karena perjanjian yang dibuat antar para pihak ini pada dasarnya tidak harus dibuat dalam bentuk tertentu (tertulis). Perjanjian yang ada kenyataannya dilakukan secara bebas, termasuk perjanjian lisan dan tidak tertulis sebagaimana kontrak dagang elektronik.

Tentang pembuktian telah terjadinya suatu kontrak dagang elektronik, biasanya baru terjdi apabila ada sengketa diantara para pihak maka digunakan sistem pembuktian yang dianut oleh Hukum Acara Perdata, yaitu pada Pasal 164 HIR (283 RBg) dan 1093 KUH Perdata. Digital Signature dapat dipakai sebagai alat bukti namun relatif sifatnya, sebab menurut Hukum Acara Perdata Indonesia, apabila ada sengketa, kemudian sengketa diserahkan kepada hakim dalam penyelesaiannya, maka hakim tidak dapat menolak perkara tersebut dengan alasan tidak ada hukumnya (asas ius curia novit). Pasal 12 UU No. 8 Tahun 1987 tentang Dokumen Perusahaan yang berbunyi : Dokumen perusahaan dapat dialihkan ke dalam mikrofilm atau media lainnya. Setelah proses pengalihan dilakukan untuk menjadikan dokumen perusahaan ini mempunyai kekuatan alat bukti, maka perlu ada proses legalisasi.

\section{DAFTAR PUSTAKA}

\section{A. Buku}

Abdul Kadir Muhammd, Hukum Perikatan, PT. Aditya Bakti, Bandung, 1992 


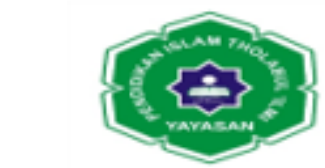

Jurnal Ilmiah METADATA

AsrilStimpul, SH, LL.M, Hukum Internet Pengenalan Mengenai Masalah Hukum di Cyberspace, PT. Citra Aditya Bhakti, Bandung, 2001

Joni Emirzon., Hukum Bisnis Indonesia, ProyekPeningkatan Penelitian Pendidikan Tinggi Direktorat Jenderal Pendidikan Tinggi, Departemen Pendidikan Nasional, Jakarta, 2002

Mariam Darus Badrulzaman., Kompilasi Hukum Perikatan, PT. Citra Aditya Bhakti, Bandung, 2001

M. Arsyad Sanusi., E-Commerce Hukum dan Solusinya, PT. Mizan Grafika, Jakarta, 2001

Richardus Eko Indrajit., Pengantar Konsep Dasar Manajemen Sistem Informasi dan Teknologi Informasi Penerbit PT. Elex Media Komputindo, Jakarta, 2000,

------.,E-commerce Kiat dan Strategi Bisnis Di Dunia Maya, PT. Elex Media Komputindo Grmaedia, Jakarta, 2001

R. Subekti., Aneka Perjanjian, PT. Intermasa, Jakarta, 1992

Riyeke Ustadiyanto., Framework E-Commerce, Penerbit Andi, Yogyakarta, 2001

Wahana Komuter Semarang., Apa dan Bagaimana E-Commerce, Andi, Yogyakarta, 2002

\section{B. Unddang-Undang}

Undang-Undang Nomor 11 Tahun 2008 Tentang Informasi dan Transasi Elektronik.

\section{B. Undang-Undang}

Undang-Undang Nomor 30 Tahun 1999 Tentang Arbitrase dan Alternatif Penyelesaian Sengketa. 